\title{
Removal of phosphorus from secondary effluents using infiltration-percolation process
}

\author{
Mahmoud Bali ${ }^{1} \cdot$ Moncef Gueddari $^{2}$
}

Received: 19 July 2016 / Accepted: 21 March 2019 / Published online: 27 March 2019

(c) The Author(s) 2019

\begin{abstract}
Intermittent infiltration-percolation is an extensively used treatment process which is capable of oxidizing and decontaminating wastewater. The main purpose of this study was to evaluate the efficiency of this treatment process regarding particularly the removal of phosphorus from urban wastewater effluents. The phosphorus removal mechanisms that may occur in sand filters were investigated. Results confirmed that infiltration-percolation is performed as an advanced treatment technique for suspended solids, organic matter and nitrogen. However, it is less efficient concerning the reduction of orthophosphate. The experimental study has shown the influence of the filter depth, the hydraulic load and its fractionation on phosphorus removal. Analyses of the percolating water sampled at 50,100 and $150 \mathrm{~cm}$ bed depths showed that efficiency of phosphorus removal increased significantly with the depth of the filtering medium. Results indicated that providing more and smaller sequences improves the efficiency of orthophosphate retention. During the experimentation period, phosphorus removal rates do not seem to be affected by the variation of temperature. The scatter plots and the Pearson's correlation coefficient indicate that there is no apparent linear pattern between orthophosphate retention rates and temperature. This finding confirms that phosphorus removal is not attributed to microbial uptake but it is mainly governed by physical-chemical mechanisms such as adsorption and precipitation.
\end{abstract}

Keywords Infiltration-percolation $\cdot$ Phosphorus removal $\cdot$ Sand filters $\cdot$ Wastewater $\cdot$ Mechanisms

\section{Introduction}

Phosphorus poses a major environmental problem due to its high contribution to eutrophication of freshwater bodies (Abou Nahra 2006). Eutrophication is a condition of an aquatic ecosystem where high nutrient concentrations, such as nitrogen and phosphorus, stimulate algal blooms, degrading the water quality in these aquatic ecosystems (Ritter and Shirmohammadi 2001). Therefore, controlling phosphorus discharged from municipal and industrial wastewater treatment plants is a key factor in preventing eutrophication of surface waters. Phosphorus occurs in many forms in wastewater. The types of phosphate present typically are categorized according to physical characteristics into dissolved and

Mahmoud Bali

mahmoud.bali@yahoo.fr

1 Higher Institute of Water Sciences and Techniques, University of Gabès, Gabès, Tunisia

2 Faculty of Sciences of Tunis, University of Tunis El Manar, Tunis, Tunisia particulate fractions and chemically into orthophosphate, polyphosphate and organic phosphate (Sedlak 1991). All polyphosphate forms gradually hydrolyze in aqueous solution and revert to the orthophosphate form (Mostafa 2012). According to Prigent (2012), orthophosphate $\left(\mathrm{PO}_{4}-\mathrm{P}\right)$ is the most abundant form in domestic wastewater. It represents $60-85 \%$ of total phosphorus due to the hydrolysis of polyphosphates and organic phosphates.

Phosphorus originates in wastewater from fecal and waste materials, synthetic detergents, household cleaning products and industrial, institutional and commercial uses.

The removal of phosphorus (P) from wastewater is of major concern (Iordache et al. 2014). During the recent years, eutrophication phenomenon has been posing as a serious menace for water bodies (Ruzhitskaya and Gogina 2017). P releases due to anthropogenic activity promote this phenomenon in aquatic ecosystems and negatively affect their natural equilibrium. Total removal or at least a significant reduction of this nutrient became mandated and common in most countries (De-Bashan and Bashan 2004; 
Bunce et al. 2018). For this reason, limits for $\mathrm{P}$ discharge into aquatic ecosystems have been made more rigorous.

Recently, researchers worldwide pay much attention to develop innovative treatment methods and improve the existing ones to remove efficiently phosphorus from urban and industrial wastewaters. Various P removal technologies, based on chemical, physical and biological methods, have been implemented in wastewater treatment systems (Wilfert et al. 2015). Chemical methods are generally avoided due to high cost of reagents and also because these methods produce supplementary pollution. Physical-chemical means involve high expenditure of the process (Ruzhitskaya and Gogina 2017). The biological method of P removal can achieve a high removal rate if it is properly conducted. However, in most cases it cannot accomplish stable removal rate of this nutrient.

Research and field experiments have shown that intermittent infiltration-percolation can provide significant removal efficiency of phosphorus if properly designed and operated (Bali 2012). Infiltration-percolation is a commonly used treatment process which is capable of oxidizing and decontaminating wastewater (Mottier et al. 2000; Eturki et al. 2011; Bali et al. 2010). It has been developed as tertiary treatment of secondary effluents in several Mediterranean countries (Auset et al. 2005; Bali et al. 2011). It can be used as an alternative method for phosphorus removal. The main advantage of this method is no sludge production as compared to chemical precipitation. It is particularly adapted to wastewater reutilization projects and to the recharge of shallow groundwater planned to be used for the inter-seasonal storage of purified water (Brissaud et al. 1989). Physical, chemical and biological processes are developed in the porous medium, guaranteeing the removal of different pollutants from wastewater. Infiltration-percolation technique has been increasingly used for the treatment of primary or secondary wastewater effluents because of its low energy and maintenance requirements (Auset et al. 2005; Brissaud and Lesavre 1993; Stevik et al. 2004). It represents a simple, low-cost method of wastewater treatment in developing countries and even in developed ones (Auset et al. 2005). It consists in the intermittent application of sewage on buried sand filters or permeable native soils. The infiltered water percolates through unsaturated porous medium. The treated water is collected by a drainage system or percolates down to the under lying aquifer (Mottier et al. 2000). The performance of an intermittent sand filter depends on the type and biodegradability of the wastewater, the environmental factors within the filter and the design characteristics of the filter. The most important environmental factors that determine the effectiveness of treatment are media reaeration and temperature. Reaeration makes oxygen available for the aerobic decomposition of the wastewater. Temperature directly affects the rate of microbial growth, chemical reactions and other factors that contribute to the stabilization of wastewater within the sand filter (EPA 1999).

The main purpose of this work was to determine the efficiency of infiltration-percolation process regarding phosphorus removal from wastewaters.

\section{Materials and methods}

Experiments were investigated in $100 \mathrm{~m}^{2}$ infiltration-percolation basin located at Dissa agriculture perimeter in the north of Gabès city (southeast of Tunisia).

The filter is a trapezoidal basin with $2.0 \mathrm{~m}$ in height and filled with $30 \mathrm{~cm}$ of coarse gravel and $1.5 \mathrm{~m}$ of sand. The mean grain size of sand $\left(d_{50}\right)$ is $0.26 \mathrm{~mm}$, and the uniformity coefficient of the particle size distribution $\left(d_{60} / d_{10}\right)$ is 1.93 . A polyethylene pipe with $0.5-\mathrm{cm}$ holes was used to drain filtered water out. The experimental arrangement is depicted in Fig. 1. The sand filter was fed with activated sludge effluents from Gabès treatment plant. In this study, the operation mode conditions rotated through a 7-day cycle consisting of a 4-day flooding period and 3-day drying period. During the operation phases, the daily hydraulic loads were 0.27 and $0.40 \mathrm{~m}^{3} \mathrm{~m}^{-2}$ of sand basin. Alternation of operational and drying periods has always been considered essential to infiltration-percolation and soil aquifer treatment; it is the only practical way to manage clogging at the surface and in the core of filtrating beds (Brissaud et al. 2003).

Wastewater was spread uniformly over the surface area through a distribution system of perforated pipes (3-mmdiameter holes with a density of 20 holes $^{-1}$ ). Percolating water was sampled at $0.5,1$ and $1.5 \mathrm{~m}$ bed depths during several feeding-drainage cycles.

In order to assess the influence of distributing the daily hydraulic load on infiltration-percolation performances, a

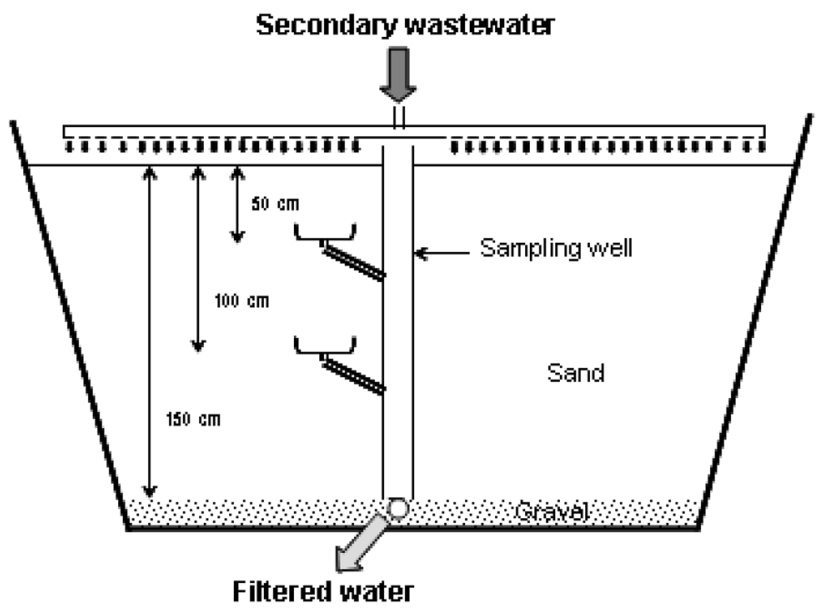

Fig. 1 Schematic drawing of the sand filter (not to scale) 
load of $0.40 \mathrm{~m}^{3} \mathrm{~m}^{-2}$ has been split into two or three applications per day. The secondary effluent and percolating water were analyzed, according to standard methods, for suspended solids (SS), chemical oxygen demand (COD) and 5-day biochemical demand $\left(\mathrm{BOD}_{5}\right)$, ammonium nitrogen $\left(\mathrm{NH}_{4}-\mathrm{N}\right)$, nitrate nitrogen $\left(\mathrm{NO}_{3}-\mathrm{N}\right)$, total Kjeldahl nitrogen $(\mathrm{TKN})$, orthophosphate $\left(\mathrm{PO}_{4}-\mathrm{P}\right)$ and complete alkalimetric title (CAT). Dissolved oxygen, $\mathrm{pH}$ and electric conductivity were measured (Table 1).

Scatter plots were used to investigate the relationship between physical and chemical parameters. They provide a visual representation of the correlation, or relationship between two variables. Pearson's correlation coefficient $(r)$ was also used to measure the strength of the association between the two variables.

\section{Results and discussion}

\section{Physical-chemical performances}

The experimental results showed a total elimination of suspended solids (Table 2). These results agree with the findings of Healy et al. (2006) who observed a removal rate of SS up to $99 \%$ using sand filters.

When treating a load of $0.27 \mathrm{~m}^{3} \mathrm{~m}^{-2}$ day $^{-1}$, the average reductions of COD and $\mathrm{NH}_{4}-\mathrm{N}$ were 81.85 and $86.49 \%$, respectively. Residual concentrations were 23.90 and $5.69 \mathrm{mg} \mathrm{L}^{-1}$, respectively. COD concentration in the treated water is inferior to the limit value $\left(125 \mathrm{mg} \mathrm{L}^{-1}\right)$ for discharge into maritime domain as restricted by the Tunisian directives (2018-315).

TKN decreased significantly in the filtered water as compared to the applied secondary effluent. The results showed

Table 1 Analytical methods used in this study

\begin{tabular}{ll}
\hline Parameter & Analytical method \\
\hline $\begin{array}{l}\text { pH and electrical conductivity } \\
\text { Dissolved oxygen }\end{array}$ & $\begin{array}{l}\text { These parameters were measured using a multi-parameter probe HACH, model DR2010 } \\
\text { It was measured with an oximeter Ponselle } \\
\text { TS }\end{array}$ \\
$\begin{array}{l}\text { This parameter was determined by microfiltration through a glass microfiber membrane } \\
\text { (Whatman GF/C, } 45 \text { m) }\end{array}$ \\
$\begin{array}{ll}\text { It was determined by the standard AFNOR T90-036 method } \\
\mathrm{COD}\end{array}$ & $\begin{array}{l}\text { It was determined by the standard AFNOR T90-103 method using BOD meter HACH } \\
\mathrm{TKN}\end{array}$ \\
$\mathrm{NH}_{4}-\mathrm{N}$ & It was determined by the standard AFNOR T90-101 method \\
$\mathrm{NO}_{3}-\mathrm{N}$ & It was determined by the standard AFNOR T90-1010 method \\
$\mathrm{PO}_{4}-\mathrm{P}$ & It was determined by the standard AFNOR T90-015 method \\
\hline
\end{tabular}

Table 2 Physicochemical characteristics of secondary effluents and filtered water (mean values)

\begin{tabular}{|c|c|c|c|c|c|c|c|c|c|}
\hline \multirow{2}{*}{$\begin{array}{l}\text { Hydraulic } \\
\text { load, } H\end{array}$} & \multicolumn{9}{|l|}{ Parameter } \\
\hline & $\overline{\mathrm{COD}\left(\mathrm{mg} \mathrm{L}^{-1}\right)}$ & $\mathrm{TKN}\left(\mathrm{mg} \mathrm{L}^{-1}\right)$ & $\begin{array}{l}\mathrm{NH}_{4}-\mathrm{N} \\
\left(\mathrm{mg} \mathrm{L}^{-1}\right)\end{array}$ & $\begin{array}{l}\mathrm{NO}_{3}-\mathrm{N} \\
\left(\mathrm{mg} \mathrm{L}^{-1}\right)\end{array}$ & $\begin{array}{l}\mathrm{PO}_{4}-\mathrm{P} \\
\left(\mathrm{mg} \mathrm{L}^{-1}\right)\end{array}$ & $\mathrm{SS}\left(\mathrm{mg} \mathrm{L}^{-1}\right)$ & $\mathrm{pH}$ & $\begin{array}{l}\text { Conduc- } \\
\text { tivity } \\
\left(\mathrm{ms} \mathrm{cm}^{-1}\right)\end{array}$ & $\begin{array}{l}\text { Dis- } \\
\text { solved } \mathrm{O}_{2} \\
\left(\mathrm{mg} \mathrm{L}^{-1}\right)\end{array}$ \\
\hline \multicolumn{10}{|c|}{$H=0.27 \mathrm{~m}^{3} \mathrm{~m}^{-2} \mathrm{day}^{-1}$} \\
\hline $\mathrm{SE}^{\mathrm{a}}$ & 131.70 & 50.09 & 42.10 & 2.70 & 29.61 & 106.10 & 7.22 & 4.00 & 4.88 \\
\hline $\mathrm{FW}^{\mathrm{a}}$ & 23.90 & 5.98 & 5.69 & 33.39 & 10.48 & 0 & 7.14 & 4.86 & 3.47 \\
\hline RR $(\%)$ & 81.85 & 90.07 & 86.49 & - & 64.61 & 100 & - & - & - \\
\hline \multicolumn{10}{|c|}{$H=0.40 \mathrm{~m}^{3} \mathrm{~m}^{-2} \mathrm{day}^{-1}$} \\
\hline $\mathrm{SE}^{\mathrm{b}}$ & 144.81 & 49.93 & 43.44 & 3.76 & 27.00 & 110.08 & 7.24 & 3.92 & 5.72 \\
\hline $\mathrm{FW}^{\mathrm{b}}$ & 37.09 & 6.76 & 6.55 & 35.45 & 9.98 & 0 & 7.08 & 4.95 & 3.30 \\
\hline RR (\%) & 74.38 & 86.46 & 84.92 & - & 63.00 & 100 & - & - & - \\
\hline
\end{tabular}

$S S$ suspended solids, $S E$ secondary effluent, $F W$ filtered water, $R R$ removal rate

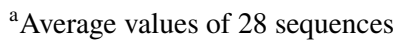

${ }^{\mathrm{b}}$ Average values of 17 sequences 
that the sand filter is very effective for the removal of TKN from the wastewater. The mean removal efficiency reached $90 \%$ (Table 2); residual TKN was $5.98 \mathrm{mg} \mathrm{L}^{-1}$ which is inferior to the limit value for discharge $\left(30 \mathrm{mg} \mathrm{L}^{-1}\right)$. High nitrification rates led to high nitrate production. The $\mathrm{NO}_{3}-\mathrm{N}$ concentration increased significantly in the percolating water. Mean nitrate concentration was 2.7 and $33.39 \mathrm{mg} \mathrm{L}^{-1}$ in the applied effluent and filtered water, respectively. The significant increase in the $\mathrm{NO}_{3}-\mathrm{N}$ concentration could be attributed to the conversion of $\mathrm{NH}_{4}-\mathrm{N}$ to nitrate form due to the oxidation reactions during the treatment process. These high performances of COD and nitrogen oxidation are evidences of the aerobic state of the sand filter, which was confirmed through dissolved oxygen monitoring at the filter outlet (Table 2). Intermittent infiltration allows maximizing the convective renewal of the air phase (Boller et al. 1993). With a load of $0.40 \mathrm{~m}^{3} \mathrm{~m}^{-2} \mathrm{day}^{-1}$, there was indication of a decrease in the oxidation capacity. Removal efficiencies of COD, TKN and $\mathrm{NH}_{4}-\mathrm{N}$ were $74.38,86.46$ and $84.92 \%$, respectively. Residual concentrations of these chemical parameters are conforming to the limit values imposed by the Tunisian regulation (2018-315). Similar results were obtained by Eturki et al. (2011).

\section{Phosphorus removal mechanisms}

In order to assess the influence of the filter depth on orthophosphate retention, analyses have been performed on the secondary effluent, percolating water at three different depths along the unsaturated sand profile. Phosphorus treatment efficiency was evaluated by subtracting the effluent from the influent concentrations. The average concentration of orthophosphate registered in the influent during the period of study was about $28.3 \mathrm{mg} \mathrm{L}^{-1}$. This concentration exceeds the limit value $\left(2 \mathrm{mg} \mathrm{L}^{-1}\right)$ imposed by the Tunisian directives.

The particulate phosphorus (mineral and/or organic) is physically retained by filtration on the surface of the filter bed. The removal of the dissolved portion of phosphorus can be achieved by physical-chemical (adsorption and precipitation) or biological processes (Kim 2014). The adsorption of the inorganic soluble phosphorus can be performed on the mineral and/or organic support (microbial biofilm) of the filtering mass. Phosphorus sorption in the filter is limited by the retention capacity of the porous medium (Bali 2012). Figure 2 shows the mean removal efficiencies of phosphorus at 50,100 and $150 \mathrm{~cm}$ bed depths for two daily hydraulic loads, $H\left(0.27\right.$ and $\left.0.40 \mathrm{~m}^{3} \mathrm{~m}^{-2}\right)$. Whatever the applied hydraulic load, efficiency of $\mathrm{PO}_{4}-\mathrm{P}$ reduction increased with the filter depth. The elimination of orthophosphate appeared to be highly dependent on both the filter depth and the daily hydraulic load. For instance, when treating $0.27 \mathrm{~m}^{3} \mathrm{~m}^{-2}$ day $^{-1}$, the mean removal rates

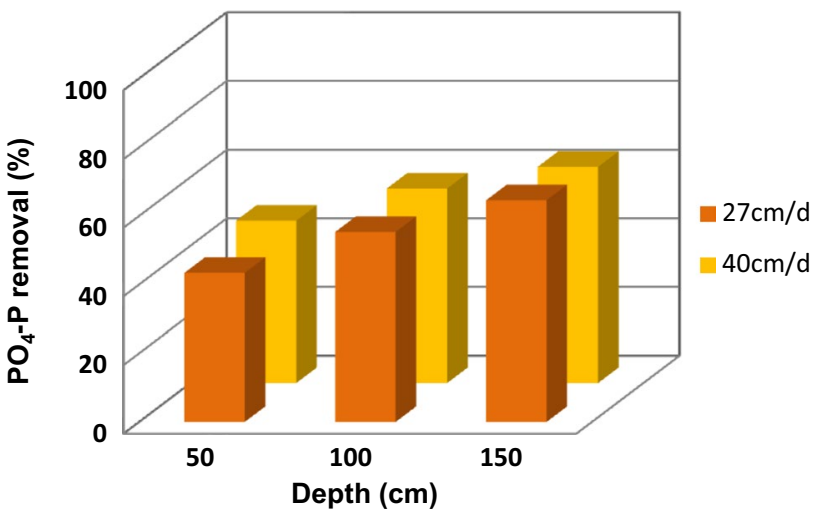

Fig. 2 Mean $\mathrm{PO}_{4}-\mathrm{P}$ removal rates along the sand filter profile for two hydraulic loads ( 27 and $40 \mathrm{~cm} \mathrm{day}^{-1}$ )

of phosphorus were $43.40,55.35$ and $64.61 \%$ at 50,100 and $150 \mathrm{~cm}$ depths, respectively. For a filter depth of $150 \mathrm{~cm}$, the average removal $\mathrm{PO}_{4}-\mathrm{P}$ was $64.61 \%$ for $H=0.27 \mathrm{~m}^{3} \mathrm{~m}^{-2}$ and $63 \%$ for $H=0.40 \mathrm{~m}^{3} \mathrm{~m}^{-2}$. These efficiencies are consistent with the works of Eturki et al. (2011) and Chennaoui et al. (2014).

Results showed that orthophosphate removal mainly occurred in upper sand layers. However, lower layers significantly contributed to water treatment performances. The achievement of significant reduction of phosphorus requires a minimum water residence time. Increasing the filter depth allows to increase the water residence time which leads retaining phosphorus in the porous medium. The decrease in orthophosphate reduction when the applied hydraulic load increased can be explained by the decrease in water residence time in the sand filter. The reason is that high hydraulic load increases water flow in the porous medium. This results in greater transport of pollutants through the filter, which decreases the residence time of wastewater in the sand bed. In consequence, efficiency of orthophosphate removal decreases when treating a high hydraulic load.

The reduction of orthophosphate was shown to be closely related to the daily number of feeding-drainage cycles, $f$ (fractionation factor). For instance, the removal rates of $\mathrm{PO}_{4}-\mathrm{P}$ were $61.4,71.6$ and $77.2 \%$ for $f=1,2$ and 3 , respectively (Fig. 3). Brissaud et al. (1999) demonstrated that the lower the $f$ value, the shorter the water detention times for an increased part of the water flow. Therefore, increasing the fractionation of the daily hydraulic load allows retaining phosphorus in the filtrating bed. According to Brooks et al. (2000), the relationship between removal rate and residence time was exhibited as two phases of soluble reactive phosphorus removal. The first suggests a rapid reaction that is attributed to adsorption and the second, slower reaction, suggests the result from either chemical precipitation or incorporation of the adsorbate into the solid matrix. Residence time is clearly a significant factor in optimizing phosphorus 


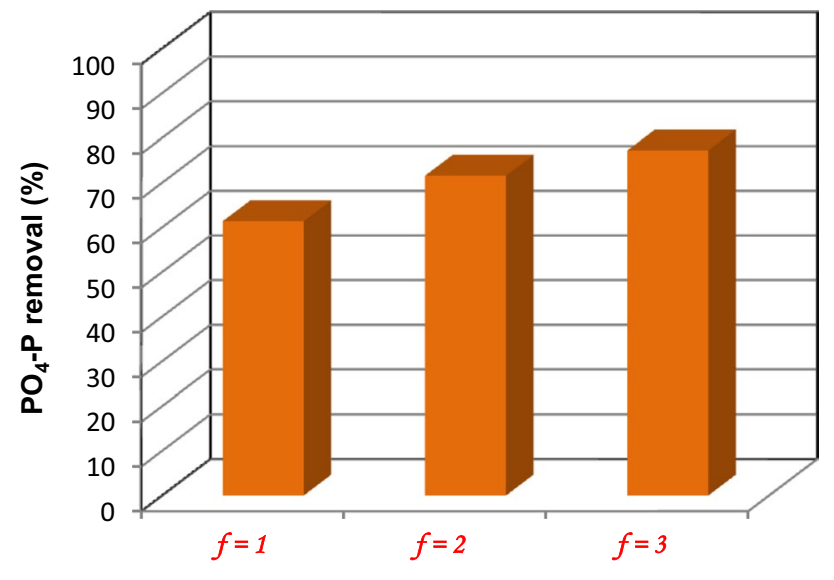

Fractionation of the hydraulic load

Fig. 3 Influence of fractionation on $\mathrm{PO}_{4}-\mathrm{P}$ removal

removal in design of full-scale infiltration-percolation systems. The removal of phosphorus in infiltration-percolation devices may occur by two possible ways: assimilation by microorganisms and fixing to the filter material. Figures 4 and 5 indicate the essential mechanisms of phosphorus retention that may occur in the sand filter. Figure 4 shows the scatter plots for $\mathrm{COD}, \mathrm{NH}_{4}-\mathrm{N}$ and $\mathrm{PO}_{4}-\mathrm{P}$ against water temperature. Results indicate that water temperature highly influences the removal rates of organic matter and ammonium nitrogen. In fact, there is a very strong uphill linear relationship between the two continuous variables and the temperature. Furthermore, the Pearson's correlation coefficients were 0.91 and 0.92 for $\mathrm{COD}$ and $\mathrm{NH}_{4}-\mathrm{N}$, respectively. It has been demonstrated that temperature is one of the most important factors affecting microbial growth. In fact, it has been observed that bacteria grow quite slowly at low temperatures but increase their rate of reaction as the temperature increases. Therefore, the biodegradation of organic matter and nitrogen increases when the water temperature increases. Experimental results showed that phosphorus removal rates do not seem to be affected by low temperature. Scatter plot of orthophosphate removal rate against water temperature confirms that there is no linear relationship between the two variables. The Pearson's correlation coefficient is very close to $0(r=-0.004)$, meaning that there is a random, no apparent linear pattern between
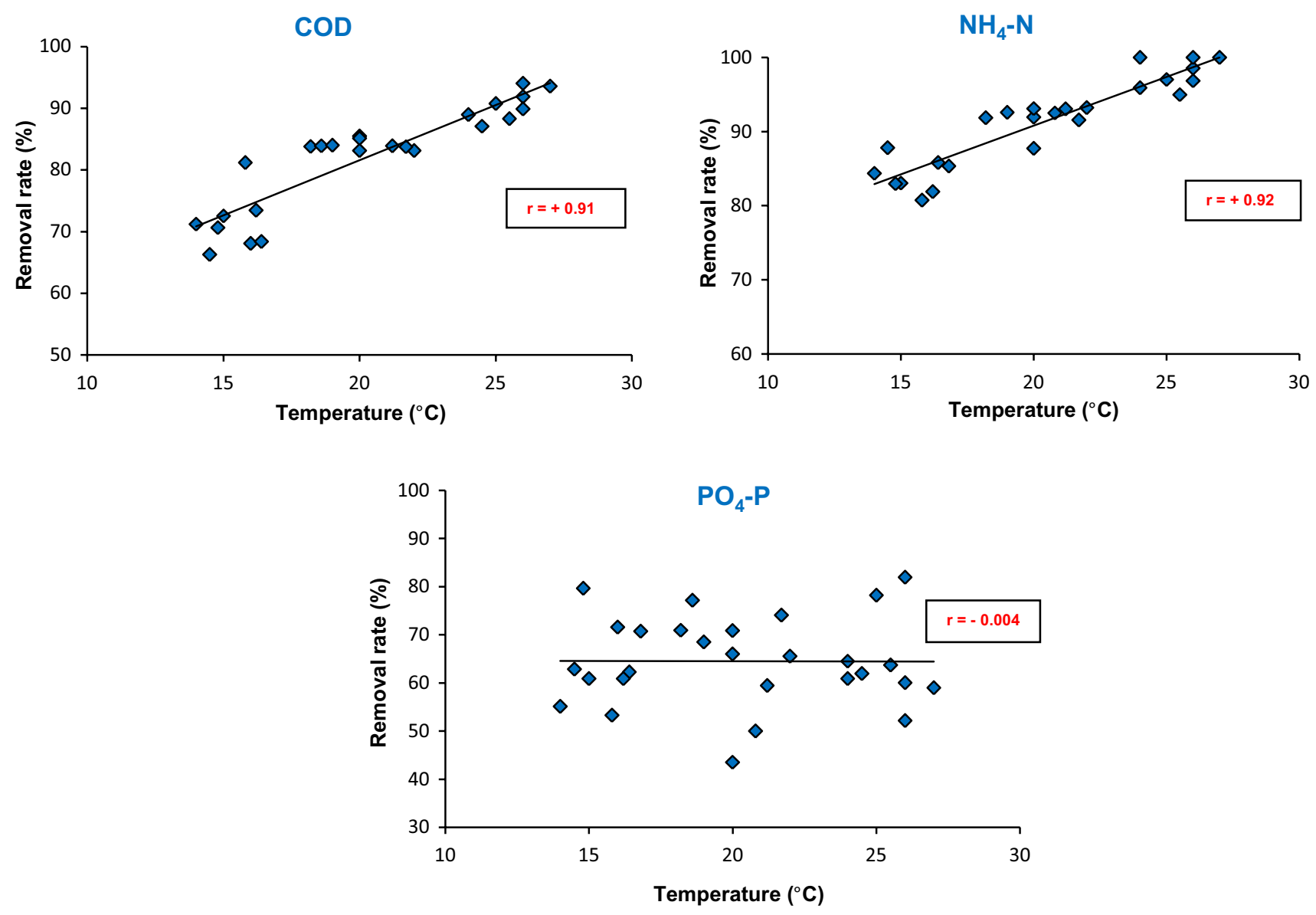

Fig. 4 Scatter plots of $\mathrm{COD}, \mathrm{NH}_{4}-\mathrm{N}$ and $\mathrm{PO}_{4}-\mathrm{P}$ against temperature 
Fig. 5 Physicochemical characteristics of the influent and effluent
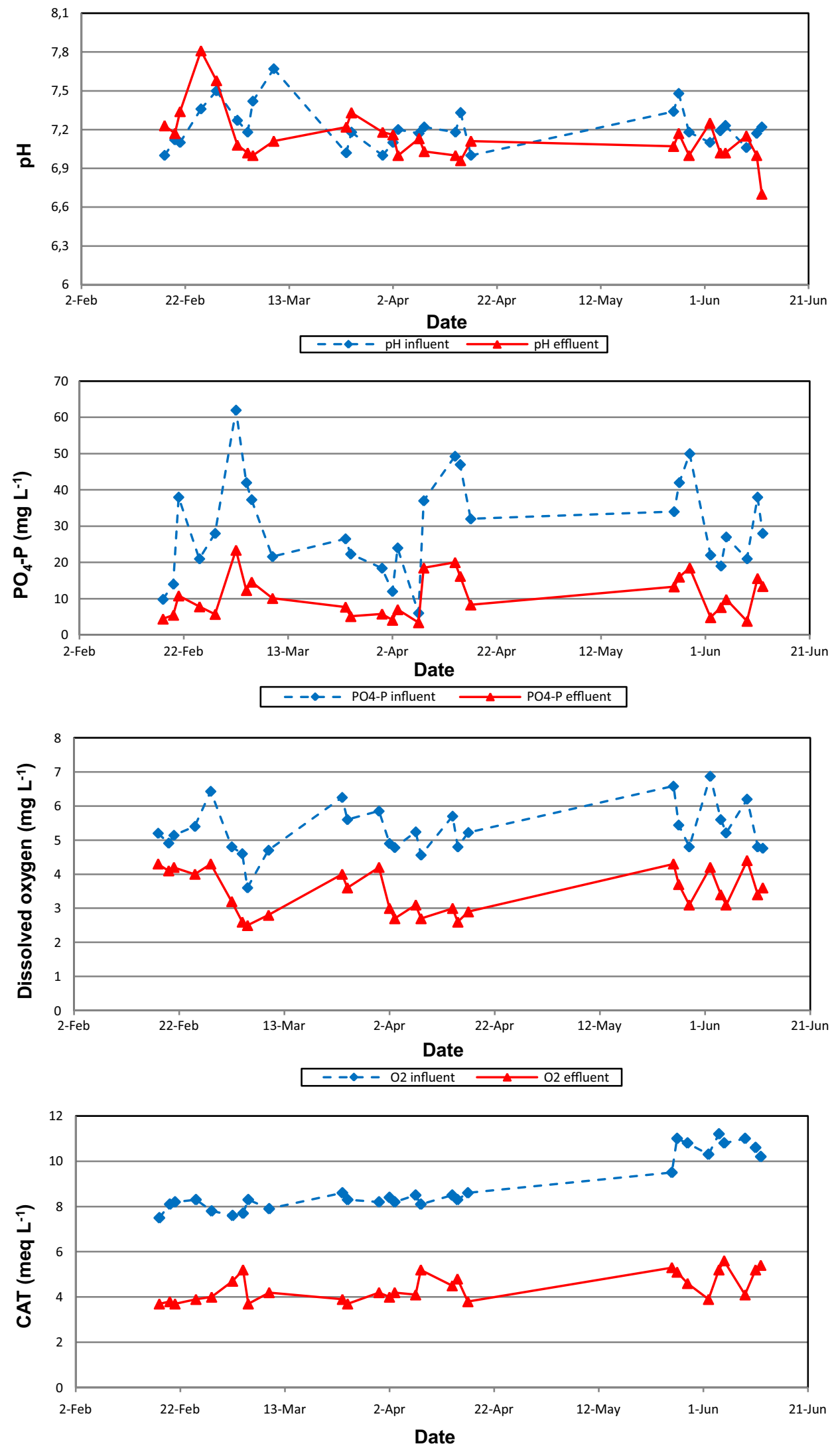
the two parameters. From the results presented above, it can be concluded that phosphorus removal is not attributed to microbial uptake but it is mainly due to physical-chemical mechanisms such as adsorption and precipitation. According to Brdjanovic et al. (1998), presence of carbon and phosphate sources at the same time under aerobic conditions has negative effects on phosphorus uptake by microorganisms. In fact, carbon sources available under these conditions will be primarily utilized for energy production. Only when the external carbon sources are exhausted, phosphorus uptake occurs (Mino et al. 1998). Numerous bacteria, constituting the microbial biofilm, are capable of storing excess amounts of phosphorus in their cells (Kermani et al. 2009). Microbial phosphorus assimilation requires the alternation of aerobic and anaerobic conditions occurred in the porous medium. During the operating cycle, the infiltration-percolation basin could be the seat of alternating aerobic and anaerobic phases likely to stimulate the development of a dephosphating biomass which is capable of removing a part of the phosphorus (Bali 2012).

Experimental results indicate that there is an undeniable consistency between the $\mathrm{PO}_{4}-\mathrm{P}$ concentrations and the other physical-chemical parameters such as $\mathrm{pH}$, dissolved oxygen and complete alkalimetric title (Fig. 5). For instance, the decrease in orthophosphate content in the filtered water is accompanied by a decrease in CAT and $\mathrm{pH}$ values. According to Makni (1995), the simultaneous variations of these parameters confirm that phosphorus retention is essentially due to the chemical processes which occur in the porous medium. The studies of Brahmi et al. (2013) confirm that the performances of infiltration-percolation systems in elimination of orthophosphate depend on electrochemical conditions of the mass filter, and soon the mineralogical composition of the sand filter. According to Bori Akdar et al. (2014), phosphorus retention in sand filters is due to sorption and precipitation phenomena. Both result from the attraction between phosphate ion and ions of $\mathrm{Al}, \mathrm{Fe}$ or $\mathrm{Ca}$ and terminate with the formation of various iron phosphates $(\mathrm{Fe}-\mathrm{P})$, aluminum phosphates (Al-P) or calcium phosphates $(\mathrm{Ca}-\mathrm{P})$. According to Abou Nara (2006), in acidic conditions, $\mathrm{PO}_{4}$ anions form covalent bonds with $\mathrm{Fe}^{3+}, \mathrm{Al}^{3+}$ and $\mathrm{Mn}^{2+}$ complexes, while in basic conditions they form bonds with $\mathrm{Ca}^{2+}$ complexes. Kim (2014) demonstrated that the complexation of phosphorus with metal cations depends on the medium $\mathrm{pH}$. For basic $\mathrm{pHs}$, the $\mathrm{P}-\mathrm{Ca}$ or $\mathrm{P}-\mathrm{Mg}$ complexes are predominant. In addition, $\mathrm{PO}_{4}$ adsorption can occur in clay minerals that have hydroxyl surfaces. The works of Arias and Brix (2005) indicated that precipitation is identified as the major phosphorus removal mechanism because of the limited adsorption capacity of the sand filters. The efficiency of phosphorus removal by chemical precipitation depends on two factors: the chemical equilibrium between the phosphorus containing water and solid and the efficiency of the solid removal process. Usually the later process controls the removal efficiency (Sathasivan 2009).

\section{Conclusion}

The first aim of this work was to evaluate the capacity of intermittent sand filter in the elimination of orthophosphate from secondary wastewater effluents. The second aim was to investigate the phosphorus removal mechanisms that may occur in this medium.

Results showed that infiltration-percolation process is performed as an advanced treatment system for suspended solids, organic matter and ammonium. However, it is less efficient concerning the removal of phosphorus. The experimental study has shown the influence of the filter depth on the removal of orthophosphate from urban wastewater. Results demonstrated that efficiency of phosphorus removal was shown to mainly depend on the daily hydraulic load and its fractionation. Data obtained during this study confirmed that phosphorus reduction is essentially governed by physical-chemical mechanisms such as adsorption and precipitation.

Infiltration-percolation technique can be used as a tertiary treatment with the aim of removing contaminants from secondary wastewater effluents.

Open Access This article is distributed under the terms of the Creative Commons Attribution 4.0 International License (http://creativeco mmons.org/licenses/by/4.0/), which permits unrestricted use, distribution, and reproduction in any medium, provided you give appropriate credit to the original author(s) and the source, provide a link to the Creative Commons license, and indicate if changes were made.

\section{References}

Abou Nahra J (2006) Modeling phosphorus transport in soil and water. Doct. Thesis, McGill University, Montreal

Arias CA, Brix H (2005) Phosphorus removal in constructed wetlands: can suitable alternative media be identified? Water Sci Technol 51(9):267-274

Auset M, Keller A, Brissaud F, Lazarova V (2005) Intermittent filtration of bacteria and colloids in porous media. Water Resour Res 41:W09408. https://doi.org/10.1029/2004WR003611

Bali M (2012) Etude expérimentale et modélisation du traitement des eaux usées domestiques par procédé d'infiltration-percolation en zone aride. Doct. Thesis, University of Tunis El Manar, Faculty of sciences, Tunis, 189p

Bali M, Gueddari M, Boukchina R (2010) Treatment of secondary wastewater effluents by infiltration percolation. Desalination 258:1-4

Bali M, Gueddari M, Boukchina R (2011) Removal of contaminants and pathogens from secondary effluents using intermittent sand filters. Water Sci Technol 64(10):2038-2043 
Boller M, Schwager A, Eugster J, Mottier V (1993) Dynamic behavior of intermittent buried filters. Water Sci Technol 28(10):99-107

Bori Akadar A, Bourioug M, Mohamed N, Alaoui-Sossé B, Cavalli E (2014) Evaluation of effectiveness of domestic wastewater treatment by infiltration through sand and pozzolana in PVC columns. Int J Environ Res 8(3):515-522

Brahmi M, Fourti O, Hassen A (2013) Disinfection of wastewater by infiltration-percolation coupled to UV irradiation in an arid Tunisian area. Hydrol Current Res 4(2):2-8

Brdjanovic D, Slamet A, Van Loosdrecht MCM, Hooijmans CM, Alaerts GJ, Heijnen JJ (1998) Impact of excessive aeration on biological phosphorus removal from wastewater. Water Res 32(1):200-208

Brissaud F, Lesavre J (1993) Infiltration-percolation in France: 10 years experience. Water Sci Technol 28(10):73-81

Brissaud F, Lefèvre F, Joseph C, Alamy Z, Landreau A (1989) Wastewater, infiltration-percolation for aquifer recharge or water reuse. Groundwater management: quantity and quality. IAHS 188, Wallingford

Brissaud F, Salgot M, Bancolé A, Floch M (1999) Residence time distribution and disinfection of secondary effluents by infiltration percolation. Water Sci Technol 40(4-5):215-222

Brissaud F, Tournoud MG, Drakids C, Lasarova V (2003) Mixing and its impact on faecal coliform removal in a stabilization pond. Water Sci Technol 48(2):75-80

Brooks AS, Rozenwald MN, Geohring LD, Lion LW, Steenhuis TS (2000) Phosphorus removal by wollastonite: a constructed wetland substrate. Ecol Eng 15:121-132

Bunce JT, Ndam E, Ofiteru ID, Moore A, Graham DW (2018) A review of phosphorus removal technologies and their applicability to small-scale domestic wastewater treatment systems. Front Environ Sci 6:1-15

Chennaoui M, Salama Y, Kader Yettefti I, Mountadar M, Assobhei O (2014) Assessment of performance wastewater treatment by infiltration-percolation: a case study. J Nat Sci Res 4:15

De-Bashan LE, Bashan Y (2004) Recent advances in removing phosphorus from wastewater and its future use as fertilizer (19972003). Water Res 38(19):4222-4246

EPA (1999) Wastewater technology fact sheet intermittent sand filters. Office of Water, Washington DC, US, EPA 932-F-99-067

Eturki S, Makni H, Boukchina R, Ben Dhia H (2011) Study of the purification performance of sand filter drained in a complementary treatment of urban wastewater under soil and climatic conditions of the southern Tunisia. JWRP 3:487-494

Healy MG, Rodgers M, Mulqueen J (2006) Performance of a stratified sand filter in removal of chemical oxygen demand, total suspended solids and ammonia nitrogen from high-strength wastewaters. J Environ Manag 83:409-415

Iordache S, Dunea D, Ianache C (2014) Optimizing nutrients removal from municipal wastewater treatment plants using computer simulation. Rev Chim (Bucharest) 65:2
Kermani M, Bina B, Movahedian H, Mehdi Amin M, Nikaeen M (2009) Biological phosphorus and nitrogen removal from wastewater using moving bed biofilm process. Iran J Biotechnol 7(1):19-27

Kim B (2014) Devenir du phosphore dans les filtres plantés de roseaux : étude de sa rétention/libération et des facteurs d'influence. Doct. Thesis, National Institute of Applied Sciences of Lyon, France, $145 \mathrm{p}$

Makni H (1995) L'oxydation et la décontamination en infiltration percolation. Doct. thesis, University of Montpellier II

Mino T, Van Loosdrecht MCM, Heijnen JJ (1998) Microbiology and biochemistry of the enhanced biological phosphate removal process. Water Res 32(11):3193-3207

Mostafa AH (2012) Effect of cement kiln dust addition on activated sludge process without primary settling for reuse applications. HBRC J 8(1):19-33

Mottier V, Brissaud F, Nieto P, Alamy Z (2000) Wastewater treatment by infiltration-percolation: a case study. Water Sci Technol 41(1):77-84

Prigent S (2012) Optimisation du traitement de l'azote et du phosphore des eaux usées domestiques adapté aux filtres plantés de roseaux. Doct. Thesis, School of Mines of Nantes, University of Nantes Angers Le Mans, 230p

Ritter WF, Shirmohammadi S (2001) Agricultural non-point source pollution: watershed management and hydrology. Lewis Publishers, Boca Raton

Ruzhitskaya O, Gogina E (2017) Methods for removing of phosphates from wastewater. In: SPbWOSCE-2016, MATEC conference, vol 106, p 07006

Sathasivan A (2009) Biological phosphorus removal processes for wastewater treatment. Water and Wastewater Treatment Technologies. Encyclopedia of Life Support Systems (EOLSS)

Sedlak R (1991) Phosphorus and nitrogen removal from municipal wastewater: principles and practice, 2nd edn. CRC Press, Taylor $\&$ Francis Group, USA

Stevik TK, Keller A, Ausland G, Hanssen JK (2004) Retention and removal of pathogen bacteria in wastewater percolating through porous media. Water Res 38:1355-1367

Wilfert P, Kumar PS, Korving L, Witkamp GJ, Van Loosdrecht MCM (2015) The relevance of phosphorus and iron chemistry to the recovery of phosphorus from wastewater: a review. Environ Sci Technol 49(16):9400-9414

Publisher's Note Springer Nature remains neutral with regard to jurisdictional claims in published maps and institutional affiliations. 